\title{
PEMBUATAN MIKROKRISTALIN SELULOSA ROTAN MANAU (Calamus manan sp.) SERTA KARAKTERISASINYA
}

\author{
Steven ${ }^{1}$, Mardiyati, R. Suratman \\ Teknik Material, Fakultas Teknik Mesin dan Dirgantara, Institut Teknologi Bandung \\ Jalan Ganesha No. 10 Bandung 40132 \\ ${ }^{1}$ xscrow_steve@yahoo.com
}

Diterima : 12 Mei 2014, Revisi akhir : 13 Oktober 2014, Disetujui terbit : 3 November 2014

\section{PREPARATION AND CHARACTERISATION OF MICROCRYSTALLINE CELLULOSE FROM MANAU RATTAN (Calamus manan sp.)}

\begin{abstract}
Rattan is one of natural resources of Indonesia which contains $30 \%-40 \%$ cellulose. Its high cellulose contents makes it very potential as a source of microcrystalline cellulose (MCC). In this research, manau rattan was characterized by using the Chesson methods. Microcrystalline cellulose was prepared by using two methods, i.e. alkalization and acid hydrolysis. Alkalization was performed by soaking manau rattan powder into sodium hydroxide 17,5\% for 8 hours. Acid hydrolysis was prepared by using sulfuric acid at a concentration of $0.1 \mathrm{M}$; $0.3 \mathrm{M}$; and $0.5 \mathrm{M}$ for 4, 6, 8, and 10 hours. The crystallinity of MCC was quantitatively measured by XRD and qualitatively measured by using FTIR. In this research, we have successfully made microcrystalline cellulose from manau rattan. The highest crystallinity MCC of $72.42 \%$ was obtained from acid hydrolysis with 0.5 M for 10 hours. The crystallinity of the MCC product increases with concentration and hydrolysis time.
\end{abstract}

Keywords: acid hydrolisis, alkalization, cellulose, manau rattan, MCC

\begin{abstract}
ABSTRAK
Rotan merupakan salah satu kekayaan hayati Indonesia yang mengisi sepuluh persen hutan di Indonesia yang memiliki kadar selulosa mencapai 30-40\%. Kadar selulosa yang cukup tinggi membuat rotan sangat berpotensi untuk dimanfaatkan sebagai bahan baku mikrokristalin selulosa (MCC). Rotan manau dikarakterisasi menggunakan metode Chesson. Pembuatan mikrokristalin selulosa terdiri atas dua tahap, yaitu alkalisasi dan hidrolisi asam. Tahap alkalisasi dilakukan dengan merendam rotan di dalam larutan $\mathrm{NaOH}$ 17,5\% selama 8 jam. Tahap hidrolisis asam dilakukan dengan menggunakan asam sulfat pada berbagai konsentrasi, yakni 0,$1 ; 0,3$ dan $0,5 \mathrm{M}$ selama 4, 6, 8, dan 10 jam. Kristalinitas dari MCC yang dihasilkan diukur dengan menggunakan XRD. Untuk mengetahui komposisi kimia serta kristalinitas MCC secara kualitatif, telah dilakukan karakterisasi dengan menggunakan FTIR. Pada penelitian ini, telah berhasil dibuat MCC yang bersumber dari rotan manau. Kristalinitas MCC tertinggi dihasilkan dengan perlakuan hidrolisis asam dengan konsentrasi $0,5 \mathrm{M}$ selama 10 jam, yaitu sebesar $72,42 \%$. Seiring dengan peningkatan konsentrasi serta waktu hidrolisis, kristalinitas MCC yang dihasilkan semakin tinggi.
\end{abstract}

Kata kunci: alkalisasi, hidrolisis asam, selulosa, MCC, rotan manau 


\section{PENDAHULUAN}

Rotan merupakan salah satu sumber hayati terbesar di Indonesia dan mengisi sekitar 10 persen hutan di Indonesia. Menurut Direktorat Bina Produksi Kehutanan, hutan Indonesia memiliki luas sekitar 143 juta hektar. Sekitar 13,40 juta hektar hutan Indonesia ditumbuhi oleh tanaman rotan dan hanya sekitar sepuluh jenis rotan yang sering dimanfaatkan untuk memenuhi kebutuhan rotan Indonesia (Jasni dkk., 2000). Salah satu jenis rotan yang sering dimanfaatkan adalah rotan manau (Calamus manan sp.). Rotan manau merupakan salah satu jenis rotan asli Indonesia yang memiliki warna batang kuning langsat dan memiliki diameter batang sekitar 10-30 mm. Kekuatan serta elastisitas yang baik menyebabkan rotan jenis ini sering dimanfaatkan sebagai bahan baku mebel, kursi, rak dan keranjang (Yuniarti, 2006). Rotan manau memiliki kandungan alfa selulosa yang cukup tinggi, yaitu sekitar 39,05\% dan menyebabkan rotan manau memiliki kekuatan yang lebih tinggi dibandingkan kebanyakan jenis rotan lainnya (Yuniarti, 2006).

Selulosa merupakan polimer hayati yang paling melimpah di alam dan dapat ditemukan hampir di seluruh bagian tubuh tumbuhan (Jasni dkk., 2000). Ketersediaannya yang melimpah, laju degradasi di tanah yang cepat, serta sifat mekanik yang baik membuat selulosa terus dikembangkan untuk memenuhi kebutuhan manusia (Brinchi, 2013; Siquerra, 2010). Untuk mendapatkan selulosa dari lignoselulosa, diperlukan suatu proses untuk memisahkan selulosa dari hemiselulosa dan lignin, yang biasa dikenal dengan proses delignifikasi. Hingga saat ini, untuk mendapatkan sifat optimum dari selulosa, para peneliti melakukan upaya-upaya untuk memodifikasi struktur selulosa. Rekayasa terbaru yang dilakukan pada selulosa adalah pembuatan mikrokristalin selulosa (MCC).

Mikrokristalin selulosa merupakan selulosa yang mengalami proses hidrolisis sebagian dan umumnya memiliki panjang 1-100 $\mu \mathrm{m}$ dengan persentase kristalinitas sebesar 55\%-85\% (Brinchi, 2013; Kalia dkk., 2011). Pembuatan mikrokristalin selulosa dari berbagai sumber hayati telah dilakukan oleh Haafiz dkk. (2013); Ilindra dan Dhake (2008); Chauhan dkk., (2009); Johar dkk., (2012); Jahan dkk. (2011). Haafiz dkk. (2013) telah membuat MCC yang berbahan dasar tandan kelapa sawit dan menghasilkan kristalinitas mencapai $87 \%$. Chauhan dkk. (2009), telah membuat MCC yang berbahan dasar kapas dan menghasilkan kristalinitas sebesar $83 \%$. Hingga saat ini, pemanfaatan MCC telah banyak diaplikasikan pada berbagai produk, antara lain electronic display, packaging, optical device, super absorbant, nanokomposit serta biokomposit (Eichorn dkk., 2009; Johar dkk., 2012; Kalia dkk., 2011). Pada penelitian ini mikrokristalin selulosa akan diekstrak dari salah satu sumber hayati Indonesia yakni rotan manau.

\section{BAHAN DAN METODE}

\section{Bahan}

Pada penelitian ini digunakan rotan manau yang didapatkan dari hutan Sulawesi. Asam sulfat dengan kemurnian 98\% diperoleh dari Central Kimia, Bandung. Natrium hidroksida diperoleh dari Bratachem, Bandung. Akuades diperoleh dari Program Studi Kimia ITB.

\section{Alat}

Pada penelitian ini digunakan mesin Brooker D8 Advance yang digunakan untuk mengukur kristalinitas dari MCC yang dihasilkan, mesin Shimadzu Prestidge 21 yang digunakan untuk mengetahui komposisi kimia didalam rotan manau sebelum dan sesudah perlakuan yang dilakukan serta Delsa Nano C Beckman Coulter yang digunakan untuk mengukur ukuran partikel dari rotan manau.

\section{Metode}

\section{Proses Ekstraksi Selulosa}

Proses ekstraksi selulosa dilakukan dengan melakukan perendaman serbuk rotan didalam larutan $\mathrm{NaOH} 17.5 \%$ pada temperatur $100^{\circ} \mathrm{C}$ selama 4, 6, 8 dan 10 jam. Perbandingan berat rotan dan larutan $\mathrm{NaOH}$ adalah 1:100 (Kaila, 2011).

\section{Proses Pembuatan MCC}

Residu yang diperoleh, direndam dalam larutan asam sulfat dengan konsentrasi $0,1 \mathrm{M} ; 0,3$ $\mathrm{M}$; dan $0,5 \mathrm{M}$ pada temperatur $100^{\circ} \mathrm{C}$ selama 4, 6 , 
8, dan 10 jam. Perbandingan berat hasil ekstraksi serbuk rotan dan larutan asam adalah 1:100 (Yu dkk., 2012).

\section{Pengukuran Kandungan Lignin}

Pengukuran kandungan lignin dilakukan dengan metode Chesson (Datta, 1981). Serbuk rotan yang telah diekstraksi selulosanya, ditimbang dengan berat 1,0 gram, dipanaskan dalam akuades pada temperatur $100^{\circ} \mathrm{C}$ selama 2 jam dan disaring. Kemudian, residu dipanaskan dalam larutan asam sulfat $0,5 \mathrm{M}$ pada temperatur $100^{\circ} \mathrm{C}$ selama 2 jam dan kemudian disaring. Hasil saringan yang didapatkan, direndam dalam larutan asam sulfat $64 \%$ selama 4 jam dan dilanjutkan dengan penambahan akuades hingga konsentrasi asam sulfat mencapai $0,5 \mathrm{M}$ dan dipanaskan pada temperatur $100^{\circ} \mathrm{C}$ selama 2 jam. Setelah proses pemanasan, residu disaring dan dikeringkan hingga massa residu tidak berubah dan ditimbang beratnya. Kandungan persen lignin dapat dihitung mengunakan Persamaan 1.

Persentase kandungan lignin

$$
=\begin{aligned}
& \text { Berat residu akhir } \\
& \text { Berat serbuk awal }
\end{aligned} \quad 100 \% \text {. }
$$

\section{Karakterisasi X-Ray Diffraction (XRD)}

Karakterisasi XRD didalam penelitian ini dilakukan di Program Studi Teknik Kimia FTI ITB. Jenis Mesin yang digunakan adalah Brooker D8 Advanced. Pengukuran dilakukan dengan $2 \theta$ yang berkisar antara $0-90^{\circ}$.

\section{Karakterisasi Fourier Transform Infra-Red (FTIR)}

Karakterisasi FTIR dilakukan di Program Studi Kimia ITB dengan menggunakan mesin Shimadzu Prestige 21. Dalam proses karakterisasi, bilangan gelombang yang direkam berkisar dari $400-4000 \mathrm{~cm}^{-1}$.

\section{Karakterisasi Particle Size Analyzer (PSA)}

Karakterisasi PSA dilakukan di Nanotech Indonesia BPPT Serpong. Dalam proses karakterisasi, dispersant yang digunakan adalah air.

\section{HASIL DAN PEMBAHASAN}

\section{Ekstraksi Selulosa dari Serbuk Rotan}

Gambar 1 memperlihatkan perlakuan alkali membuat warna serbuk rotan berubah menjadi semakin kecoklatan seiring dengan waktu dan temperatur alkalisasi. Perubahan warna pada lignoselulosa disebabkan oleh menempelnya larutan alkali yang bereaksi dengan lignin, pada serbuk rotan, sehingga warna serbuk rotan berubah menjadi kecoklatan. Warna kecoklatan yang terbentuk selama proses delignifikasi, diakibatkan adanya reaksi antara larutan alkali dan lignin yang menghasilkan larutan yang berwarna kecoklatan (Chessa, 2014). Larutan kecoklatan yang terbentuk selama proses delignifikasi biasa disebut dengan black liquor. Larutan black liquor yang terjebak didalam serbuk rotan akan mempengaruhi warna pada serbuk rotan sehingga serbuk rotan tampak berwarna lebih kecoklatan dibandingkan dengan sebelum dilakukan proses delignifikasi (Chessa, 2014; Riskiansyah, 2010).

Persentase kandungan lignin pada serbuk rotan sebelum dan sesudah mengalami perlakuan alkali dengan variasi waktu dan temperatur tertentu ditunjukkan pada Gambar 2. Kandungan lignin yang diperoleh dihitung dengan menggunakan metode Chesson (Datta, 1981).

Berdasarkan hasil eksperimen yang didapatkan, kandungan lignin pada rotan manau yang digunakan adalah sebesar $24,79 \%$. Kandungan lignin yang didapatkan dengan metode Chesson (Datta, 1981) hampir sama dengan kandungan lignin yang terdapat pada literatur yaitu sebesar 22,22\% (Kalia dkk., 2011). Dari kemiripan hasil yang didapatkan melalui ekperimen dan literatur menunjukkan bahwa metode Chesson (Datta, 1981) dapat digunakan sebagai salah satu metode untuk menghitung kandungan lignin pada lignoselulosa. Selain itu, pada Gambar 2, terlihat bahwa seiring dengan peningkatan waktu serta temperatur alkalisasi menyebabkan kandungan lignin yang terdapat didalam lignoselulosa semakin berkurang. Selain itu, pengaruh waktu alkalisasi terhadap pengurangan kandungan lignin juga dibuktikan dengan karakterisasi FTIR yang dapat dilihat pada Gambar 3. Kandungan lignin dan hemiselulosa didalam lignoselulosa ditunjukkan pada bilangan gelombang $1593 \mathrm{~cm}^{-1}$ dan $1245 \mathrm{~cm}^{-1}$ (Ilindra dan Dhake, 2008; Kalia dkk., 2011; Reddy dan Yang, 


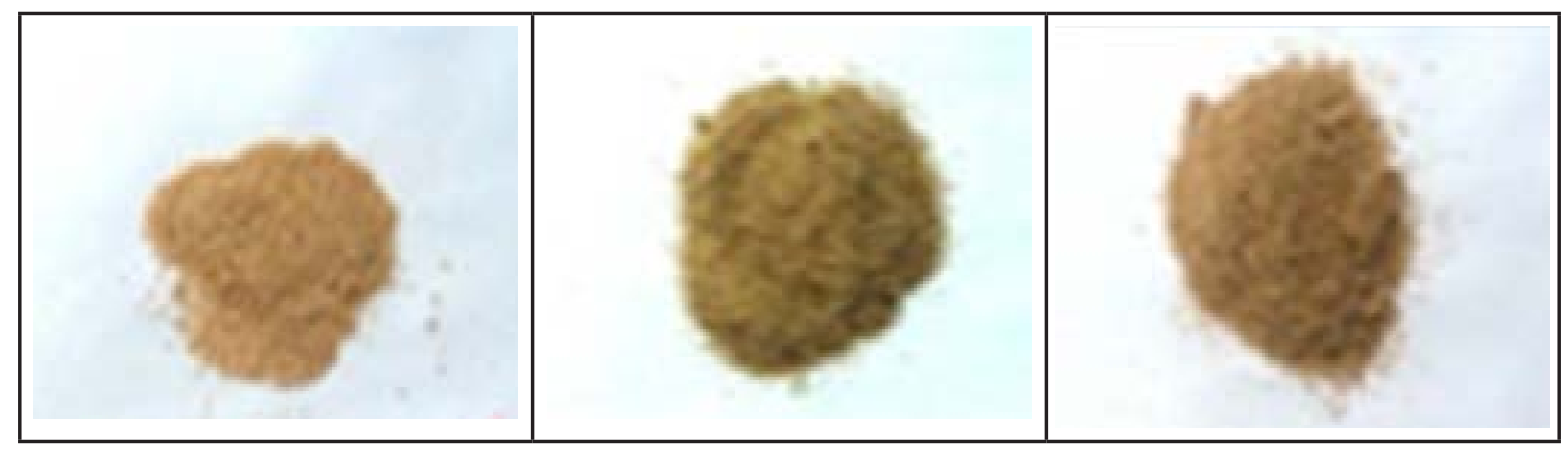

(a)

(b)

(c)

Gambar 1. Serbuk Rotan Sebelum dan Setelah Perlakuan Alkali, (a) Serbuk Rotan Tanpa Perlakuan,

(b) Serbuk Rotan yang Dialkalisasi $80^{\circ} \mathrm{C} 8 \mathrm{Jam}$ (c) Serbuk Rotan yang Dialkalisasi $100^{\circ} \mathrm{C} 8 \mathrm{Jam}$

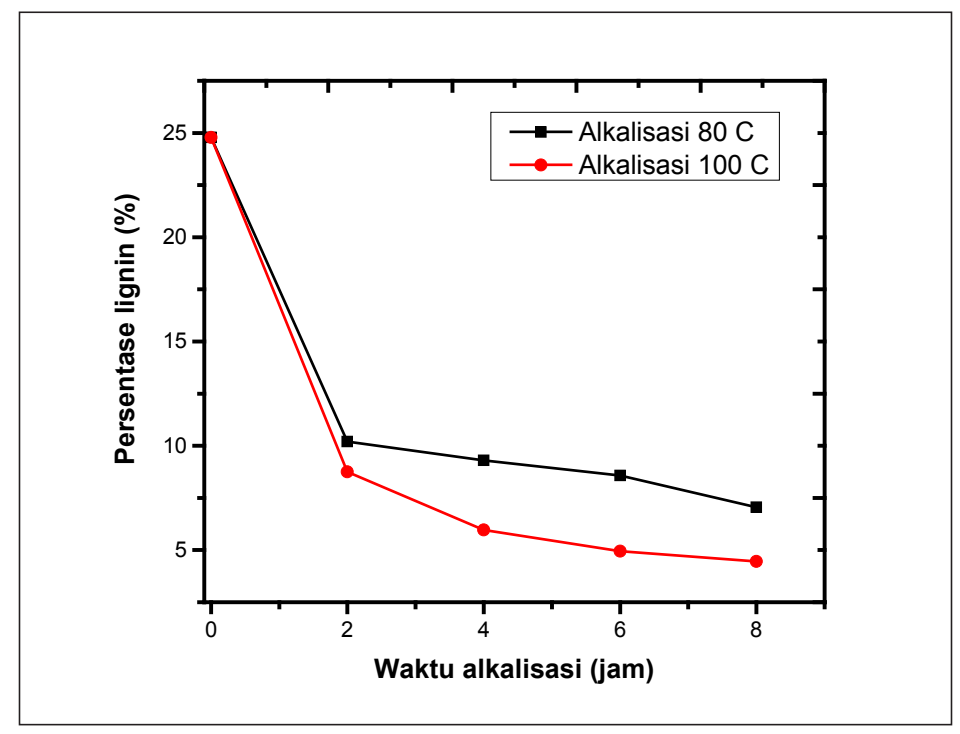

Gambar 2. Persentase Kandungan Lignin Sebelum dan Setelah Mengalami Perlakuan Alkali

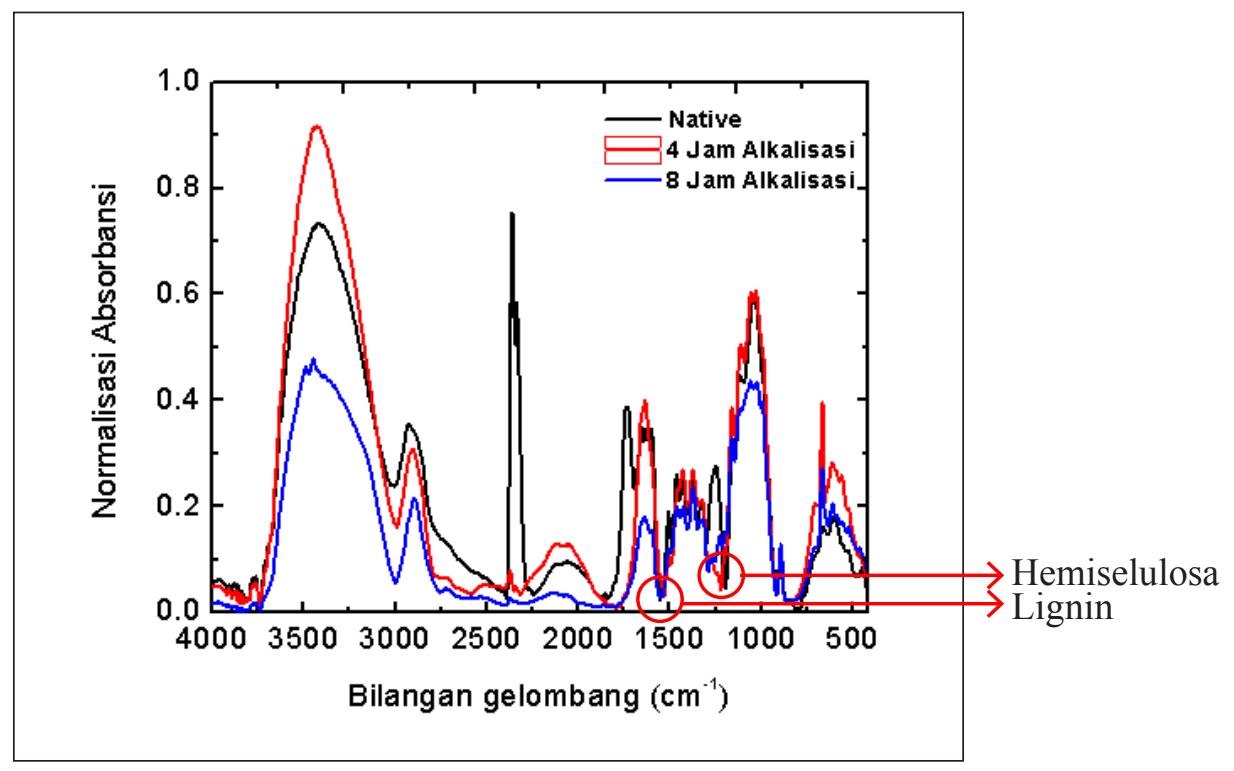

Gambar 3. Kurva FTIR Serbuk Rotan Alkalisasi $100^{\circ} \mathrm{C}$ 


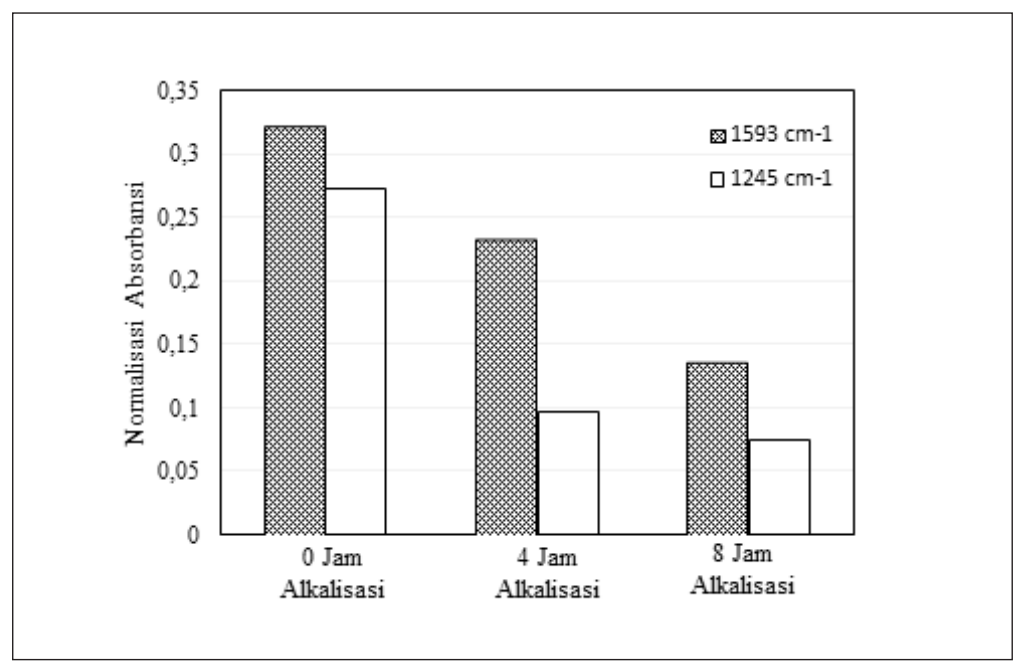

Gambar 4. Nilai Normalisasi Absorbansi pada Bilangan Gelombang $1593 \mathrm{~cm}^{-1}$ dan $1245 \mathrm{~cm}^{-1}$

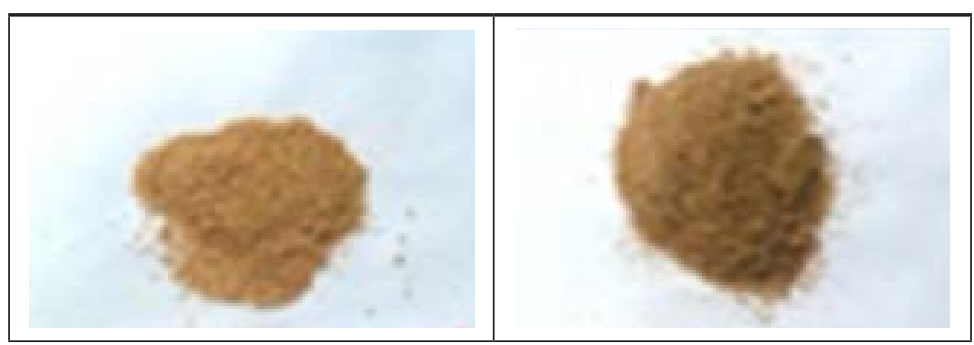

(a)

(b)

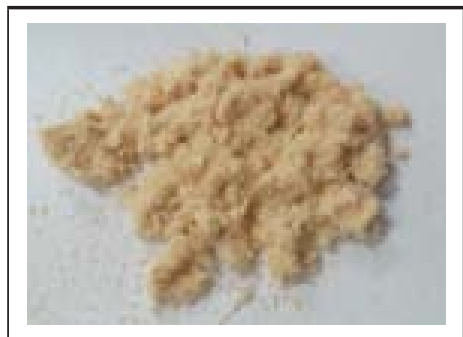

(c)

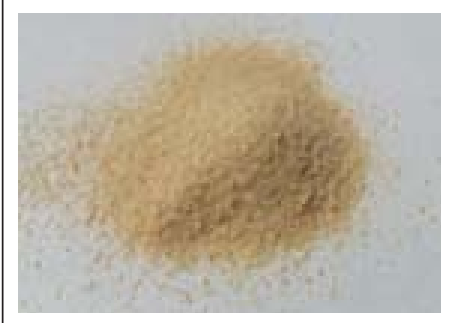

(d)

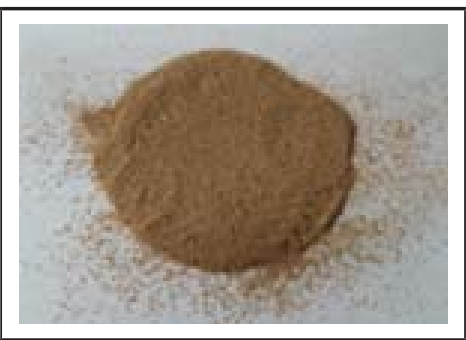

(e)

Gambar 5. Serbuk Rotan Sebelum dan Setelah Hidrolis, a) Serbuk Rotan Tanpa Perlakuan, (b) Serbuk Rotan yang Dialkalisasi $100^{\circ} \mathrm{C} 8 \mathrm{Jam}$ (c) Serbuk Rotan yang Dihidrolisis 0,1 M $10 \mathrm{Jam}$, (d) Serbuk Rotan yang Dihidrolisis 0,3 M 10 Jam, (e) Serbuk Rotan yang Dihidrolisis 0,5 M 10 Jam

2009; Riskiansyah, 2010). Pada Gambar 3 dapat terlihat terjadinya penurunan nilai absorbansi ternomalisasi pada bilangan gelombang 1593 $\mathrm{cm}^{-1}$ dan $1245 \mathrm{~cm}^{-1}$ seiring dengan perlakuan alkali. Untuk mempermudah intepretasi penurunan nilai normalisasi absorbansi pada bilangan gelombang $1593 \mathrm{~cm}^{-1}$ dan $1245 \mathrm{~cm}^{-}$ ${ }^{1}$, nilai absorbansi pada bilangan gelombang tersebut dibuat grafik batang seperti yang terlihat pada Gambar 4. Gambar 4 menunjukkan penurunan kandungan lignin dan hemiselulosa pada lignoselulosa seiring dengan peningkatan waktu alkalisasi. Pengurangan lignin yang semakin besar seiring dengan peningkatan waktu serta temperatur alkalisasi juga dikemukakan oleh Singh (2013); Iroba dkk. (2013); Reddy dan Yang, (2009); dan Chessa, (2014). Dalam eksperimen ini, persentase kandungan lignin dan hemiselulosa terendah dihasilkan oleh serbuk rotan yang dialkalisasi pada temperatur $100^{\circ} \mathrm{C}$ selama 8 jam. 


\section{Pembuatan Mikrokristalin Selulosa (MCC)}

Tampilan visual selulosa sebelum dan setelah mengalami hidrolisis dapat dilihat pada Gambar 5. Pada Gambar 5 terlihat bahwa seiring dengan peningkatan temperatur serta waktu hidrolisis menyebabkan partikel selulosa yang dihasilkan menjadi semakin halus. Partikel serbuk rotan yang semakin halus ditunjukkan melalui hasil pengujian ukuran dengan menggunakan particle size analyzer. Dari pengujian tersebut, diperoleh ukuran dari serbuk rotan tanpa perlakuan hidrolisis adalah $123 \mu \mathrm{m}$ dan diameter serbuk rotan setelah mengalami perlakuan hidrolisis pada konsentrasi $0,5 \mathrm{M}$ selama 10 jam adalah sebesar $23 \mu \mathrm{m}$. Persentase kristalinitas dari mikrokristalin selulosa yang diperoleh dengan pengukuran menggunakan XRD ditunjukkan pada Gambar 6. Pada Gambar 6 terlihat bahwa seiring dengan peningkatan konsentrasi serta waktu hidrolisis, kristalinitas MCC yang dihasilkan semakin meningkat.

Kristalinitas yang meningkat seiring dengan peningkatan waktu serta konsentrasi hidrolisis disebabkan oleh kecepatan pemotongan daerah amorf pada selulosa. Peningkatan kristalinitas

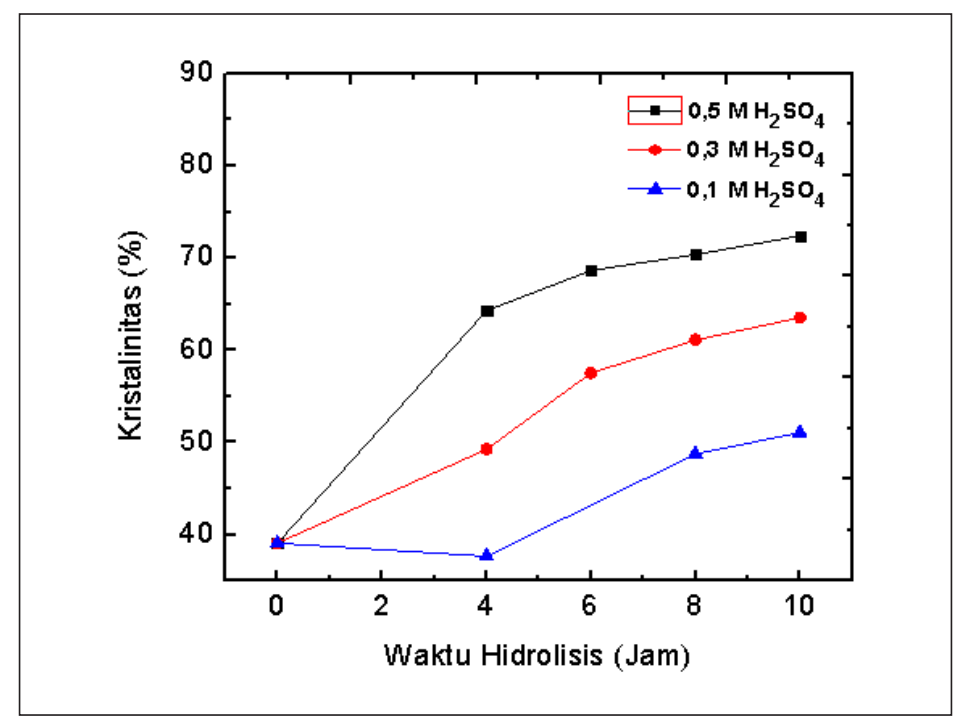

Gambar 6. Data Kristalinitas MCC pada Berbagai Konsentrasi Serta Waktu Hidrolisis

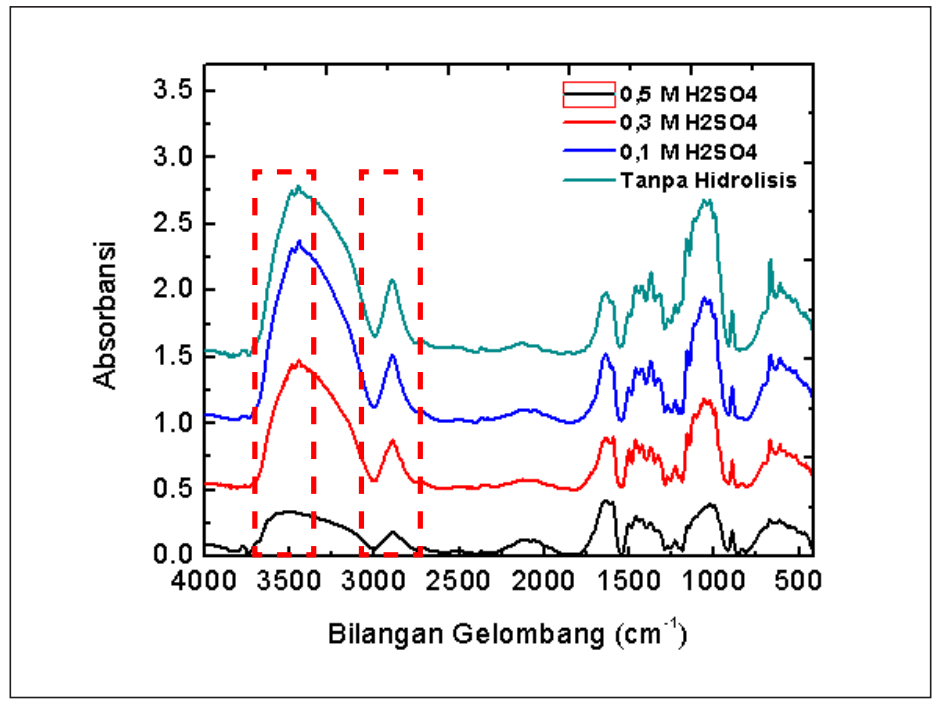

Gambar 7. Kurva FTIR Selulosa yang Dihidrolisis Pada Berbagai Konsentrasi 
MCC yang meningkat seiring dengan meningkatnya konsentrasi hidrolisis diperkuat dengan hasil analisa FTIR yang ditunjukkan pada Gambar 7. Gambar 7 menunjukkan penurunan nilai absorbansi pada bilangan gelombang 3435 $\mathrm{cm}^{-1}$ dan $2920 \mathrm{~cm}^{-1}$ seiring dengan peningkatan konsentrasi hidrolisis (Jahan dkk., 2011; Johar dkk., 2012). Menurut penurunan nilai absorbansi pada bilangan gelombang tersebut tersebut menunjukkan penurunan ikatan yang kuat pada gugus $\mathrm{C}-\mathrm{H}$ dan $\mathrm{O}-\mathrm{H}$ stretching yang mengindikasikan semakin banyaknya daerah kristalin pada MCC (Eichorn dkk., 2009; Haafiz dkk., 2013; Ilindra dan Dhake, 2008; Johar dkk., 2012; Kaila, 2012).

Penurunan jumlah $\mathrm{O}-\mathrm{H}$ dan $\mathrm{C}-\mathrm{H}$ stretching disebabkan karena rantai antar selulosa pada MCC menjadi semakin rapat sehingga mencegah terjadinya pergerakan gugus $\mathrm{O}-\mathrm{H}$ dan C-H pada selulosa dan menyebabkan jumlah gugus $\mathrm{O}-\mathrm{H}$ dan $\mathrm{C}-\mathrm{H}$ yang dapat bergerak menjadi semakin sedikit. Kristalinitas MCC tertinggi yang dihasilkan dalam penelitian ini adalah $72,42 \%$ yang dihasilkan dengan proses hidrolisis dengan konsentrasi asam sulfat $0,5 \mathrm{M}$ selama $10 \mathrm{jam}$. Nilai kristalinitas yang didapat dalam penelitian ini cukup tinggi dibandingkan dengan MCC yang didapatkan dari sumber lainnya (Jahan dkk., 2011; Johar dkk., 2012; Jasni dkk., 2000).

\section{KESIMPULAN}

Kristalinitas MCC tertinggi dihasilkan dengan perlakuan hidrolisis asam dengan konsentrasi 0,5 M selama 10 jam, yaitu sebesar $72,42 \%$. Seiring dengan peningkatan konsentrasi dan waktu hidrolisis, kristalinitas mikrokristalin yang dihasilkan semakin tinggi.

\section{UCAPAN TERIMA KASIH}

Terima kasih kepada IA-ITB yang telah memberikan dana untuk penelitian ini.

\section{DAFTAR PUSTAKA}

Brinchi, L., 2013, Production of Nanocrystalline Cellulose from Lignocellulosic Biomass, Carbohydrate Polymer, 94, 154-159

Chauhan, Y.P., Sapkal, R.S., Sapkal, V.S, Zamre, G.S., 2009, Microcrystalline cellulose from cotton rags, Int. J. Chem. Sci, 2, 681-688
Chessa, R., 2014, Pembuatan Papan Partikel Ramah Lingkungan Berbahan Dasar Sekam Padi, Tugas Akhir Sarjana, Fakultas Teknik Mesin dan Dirgantara, Institut Teknologi Bandung

Datta, R. 1981. Acidogenic fermentation of lignocellulose-acid yield and conversion of components. Biotechnology and Bioengineering 23, 9, 2167-2170

Eichorn, S.J., Dufresne, A., Aranguren, M., Marcovich, N. E., Capadona, J. R., Rowan, S. J., Weder, C., Thielemans, W., Roman, M., Rennecar, S., Gindl, W., Veigel, S., Keckes, J., Yano, H., Abe, K., Nogi, M., Nakagaito, A. N., Mangalam, A., Simonsen, J., Benight, A. S., Bismarck, A., Berglund, L. A., Peijs, T., 2009, Review : Current International Research into Cellulose Nanofibre and Nanocomposites, $J$ Mater Sci, 45, 1-33

Haafiz, M., Eichorn, S.J., Hassan, A., Jawaid, M., 2013, Isolation and characterization of microcrystalline cellulose from oil palm biomass residue, Carbohydrate Polymer, 93 , 628-634

Ilindra, A., Dhake, J.D., 2008, Microcrystalline cellulose from baggase and rice straw, Indian Journal of Chemical Technology, 15, 497499

Iroba, Kingsley L., Tabil L. G., Dumonceaux T., Baik O. D., 2013. Effect of Alkaline Pretreament on chemical composition of lignocellulosic biomass using radio frequency heating. Biosystem engineering, 116, 385-398

Jahan, M. S., Saeed, A., He, Z., Ni, Y., 2011, Jute as raw material for the preparation of microcrystalline cellulose, Cellulose, 18, 451-459

Johar, N., Ahmad, I., Dufresne, A, 2012, Extraction, preparation and characterization of cellulose fibres and nanocrystals from rice husk, Industrial Crops and Products, 37, 93-99

Kalia, S., Dufresne, A., Cherian, B. M., Kaith, B. S., Avérous, L., Njuguna, J., Nassiopoulos, E., 2011, Cellulose-based Bio and Nanocomposite: A Review, International Journal of Polymer Science, 2011, 1-35

Jasni, Martono, D., Supriana, N., 2000. Sari Hasil Penelitian Rotan. Dalam Sari Hasil Penelitian Rotan dan Bambu. Puslitbang Hasil Hutan, Bogor 
Reddy, N., Yang, Y., 2009. Extraction and characterization of natural cellulose fibres from common milkweed stems. Polymer Engineering and Science, 49, 11, 2212-2217

Riskiansyah, R. R., Ekstraksi Mikrokristalin Selulosa dari Bambu Apus (Gigantochloa apus) dan Pemanfaatannya Sebagai Penguat pada Biokomposit Pati Tapioka/MCC, Tugas Akhir, Fakultas Teknik dan Desain, Institut Teknologi dan Sains Bandung, Kota Deltamas

Singh, D. P., Trivendi, R. K., 2013. Acid and Alkaline Pretreatment of Lignocellulosic Biomass To Produce Ethanol As Biofuel. Int.J. ChemTech Res., 2013, 5(2)
Siquera, G., 2010, Cellulosic Bionanocomposites: A Review of Preparation, Properties, and Application, Polymer, 2, 728-765

Yu, M., Yang, R., Huang, L., Cao, X., Yang, F., Liu, D., 2012, Preparation and characterization of bamboo nanocrystalline cellulose, Bioresources, 7, 2, 1802-1812

Yuniarti, K., 2006, Teknologi Budidaya dan Pengelolahan Rotan dan Bambu. Prosiding Ekspose/Diskusi Hasil-Hasil Penelitian Balai Litbang Kehutanan Bali-Nusa Tenggara, 89-103 